\title{
Public Safety in Rio De Janeiro: On Track, Barely
}

Julia Michaels

Disque Denúncia, Rio's crime hotline, is located on the third floor of a 1943 art déco building atop the city's main train station. The station sits about midway along Presidente Vargas Avenue, an eight-lane avenue built by a dictator in the forties to parade his tanks and soldiers.

Parked at the entrance of the hotline building is a blue-and-white VW Bug marked with the Military Police insignia. When I first came to Brazil, in the 1980s, this is what cops drove. Many of these cars sputtered along on the first round of the country's sugar cane alcohol fuel program, not yet perfected. Between that and the Bug's sluggish pickup, criminals enjoyed a certain advantage.

On a fall afternoon,I rode an elevator - manned by an actual operator - to the third floor of the building atop the train station, to visit the founder-director of Disque Denúncia, which means "Dial an Accusation". Zeca Borges is a bearded 72-year-old who likes to wear Panama hats. He and a colleague received me in a conference room, where they showed me a PowerPoint presentation heavy on impact, and then took me on a tour.

In an open space housing staff in charge of areas such as social media, press relations, cash rewards and the "Wanted" program, Borges stopped to tell me about drug traffickers' birthdays.

In Rio, everybody knows that drug traffickers, intent on keeping good relations with the favela residents who live in their territories, hold enormous birthday barbecues, with abundant and free grilled meat and beer. Having lived here for 34 years, I of course had heard about the shindigs. But I'd never stopped to think about where 
these guys bought their supplies. You don't see narcos, AK47s slung over their shoulders, pushing shopping carts down supermarket aisles.

“They hold up truck shipments," explained Borges. "So I find out when their birthdays are, and warn trucking companies about upcoming celebrations." To make sure the traffickers know they're being watched, he posts the relevant birthday horoscopes on the program's Twitter account.

A conversation with Borges reveals much about Rio's public safety issues. For example, Disque Denúncia, which shares callers' anonymous tips with the police (housed one floor up in the same building atop the train station, which is why the VW Bug is downstairs), actually gets a lot of calls from police officers. This is because, working in an institution long riddled with corrupt and violent practices, relations with peers and higher-ups can constrain a more direct approach to crime. Also, Borges says, cops sent to act on caller tips will often apologize to perps for not being able to accept bribes; they know Disque Denúncia, a privately-sponsored entity, will be following up.

Public safety has definitely improved since Disque Denúncia came into being to free a kidnapped young man, in 1995. In those days, the homicide rate was peaking at 62 per 100,000 people, surgeons at public hospitals were pros with wounds caused by stray bullets and bigtime drug traffickers ruled over favelas home to hundreds of thousands of people.

Rio's most recent official homicide rate, for 2014, is 30 per 100,000 residents and in 2014, police killings (of people who, officially, "resist") totaled 413 (down from 1,330 in 2007, a record since these statistics were first collected in 1998). Stray bullets are a relatively rare occurrence, down from 181 reported in 2008 to 35 in 2012 (with police bullet consumption considerably less, too), and most of the bigtime drug traffickers are either dead or in jail (where, Borges admitted to me, they still run their businesses, albeit with diminished returns and leverage). 
The first time I went to the fourth floor of the building atop the train station, in 2010, for a press conference with state Public Safety Secretary José Mariano Beltrame, I left my Brazilian ID card at home so it wouldn't get stolen. After all, the area around the train station - and the Public Safety Secretariat - with Presidente Vargas Avenue's eight lanes of traffic and wide sidewalks, is infamous for snatchers of purses, cell phones and gold necklaces. Just last year, a smiling woman being interviewed by a TV Globo reporter on this very subject was startled, on camera, by a young man who tried to grab a gold chain off her neck.

I forgot I'd need that ID card to get into the press conference. But in hallowed Brazilian style, a colleague vouchsafed me to an officer and I talked my way in, getting a short lecture on the probability of finding such generosity in my native USA. The experience was so nerve-wracking and embarrassing that I almost forgot why I was going to the Public Safety Secretariat.

Some fifteen minutes after we came to the fourth floor and entered the dim, wood-paneled auditorium, Beltrame and Rio's top cops took their seats at a long table up front. As I recall, there were initial statements and then some questions - something about the next phase of pacification, the program now said to be responsible for the improvement in public safety here. Or maybe they were introducing a new Military Police chief (since 2007, Rio has had six).

Being a foreigner and a novice to Rio politics and policy, I had trouble taking in the information being provided and putting it into historical perspective -- sizing up the plan. What should I ask? The Cariocas - Rio natives - knew so much more than I did.

So that day, frazzled and overwhelmed, what most drew my attention was the giant black and white photo behind the security czar, of a train rushing down a track. After a seeming eternity of police incompetence, violence and corruption, here was Beltrame, an earnest and extremely white man with blue eyes, brought in from the 
ostensibly less complicated South of Brazil. Speaking Portuguese with the measured accent of a hick, he stirred up confidence like never before. And behind him, a giant train rushing down a track.

At last I remembered we were on top of a train station. Presumably, once the railroad concessionaire moved to other quarters, no one had bothered to take down the photo.

When it comes to public safety in Rio de Janeiro, you could spend a lot of time thinking about tracks and trains and rushing. I know I have.

For decades, up until pacification, in 2008, the Rio police fought crime by periodically invading troublesome informal settlements, or favelas. Usually, "troublesome" signaled one or more of three circumstances: a payoff deal between a drug boss and police had fallen through and was being thus renegotiated; vengeance for police killings; or an attempt to put down a war between rival drug traffickers. On such occasions, bullets found their way to innocent folks, both in and out of favelas. Students missed class; employees missed work or couldn't get home. Once calm had more or less returned, the police left.

By constitutional mandate, the Rio (and other states') police are divided, officially with the Civil Police doing intelligence work and the Military Police responsible for street work. Not only have they historically competed (and are not on speaking terms, as well), but the Civil Police has its own elite squad for street work and the Military Police has its own intelligence unit. In addition, Rio boasts a traffic policing entity and a municipal "guard", as well as forest police and highway police. There is also Brazil's FBI, the Federal Police, from whose ranks Beltrame was recruited to work in Rio. And although the constitution prohibits military activity on national territory, the armed forces have actually helped out in Rio, too. More on this, later.

3RASILIANA- Journal for Brazilian Studies. Vol. 4, n.2 (2016). ISSN 2245-4373. 
Before 2008, Rio Military Police officials undertook a couple of limited, shortlived experiments with community policing -- and then returned to their long war on crime, with the elite squad, BOPE, proudly chanting battle cries in training, sporting their insignia: a skull traversed by knives and guns.

Meanwhile, there were massacres. One night in 1993, police killed eight youths sleeping on the steps of Rio's 18th-century Candelária church, which faces the harbor and strangely, backs onto the beginning of the triumphal Presidente Vargas Avenue.

A month later in 1993 came the extermination of 21 Vigário Geral favela residents - followed by horrific crimes such as the one that reined in Brazilian media coverage, the 2002 torture and murder of undercover TV Globo journalist Tim Lopes, in the Alemão favela complex.

Three main gangs ran (and still run) drugs and weapons in and out of the city's favelas, their chiefs dominating the lives of residents like feudal lords: Red Command, Friends of Friends and Third Command. Globo, Brazil's media conglomerate, doesn't name these gangs in their reporting, refusing to legitimize them as organized crime. In my opinion, this only adds to a general lack of information about what really goes on here.

Pioneering efforts to bring down violence came, in the nineties, from civil society, with the creation of the Viva Rio, CUFA and Afroreggae NGOs, working with mediation, culture, youth and jobs for former criminals.

Meanwhile, the city grew to the West and, in areas of police absence, paramilitary gangs stepped in, extorting residents and shopkeepers, initially for security coverage and later, on bottled gas purchases, alternative public transportation, cable TV and house sales.

It seemed to most of us, in the 1990s and early 2000s, that given persistent inequality and an immature democracy, the forces of evil would continue to outweigh 
those of good, and that the best we could do was keep to our own territories, mind our business, and pray that the dreadful stories we heard might never touch us.

The year 2007 started in a particularly troublesome manner. At the very end of December 2006, the Red Command gang had attacked police stations, barracks, posts, cars and officers. An interstate bus going through the city was set on fire, killing seven passengers. Drug gangs began to war over territory, with stray bullets once again terrorizing Cariocas. In February, carjackers dragged a six-year-old hanging outside the vehicle by his seat belt, killing him. In May, gunmen ambushed and killed two Military Police officers, stealing their rifles.

Surely, it's no coincidence that the movie Elite Squad, which portrayed the reality of Rio's drug war, was also launched in 2007. It was so gut-wrenchingly popular that street sellers hawked leaked copies on downtown streets.

For Rio police, the bar was higher than ever. The city was set to host the Pan American Games in July and already pulling together its candidacy for the 2016 Olympic Games. Newly elected governor Sérgio Cabral had just appointed Beltrame, an outsider, to the state's top security post.

In his 2014 memoir Todo dia é segunda feira (Every Day is Monday), Beltrame says he knew the source of much of the 2007 violence was the Red Command, holed up in the North Zone's Alemão complex of favelas, doing its best to topple the new Secretary. After all, before Beltrame (in office now for more than eight years) Rio had seen ten secretaries in twelve years.

And so the Rio police set out for one more favela incursion, in the Alemão complex, home to 60,000 . Bigger, possibly better planned and equipped than most, the invasion came to no better result than all those that preceded it: ten wounded and 19 dead, many of these just local residents, many summarily executed. 
It was in this context that pacification - police occupation of territories under criminal control, with some degree of community relations and increased attention to social needs - was born.

As is the case with crime reduction in New York, pacification harks back to several creation myths. To my mind, its principal source - as well as its main tripup -- is the enormous socioeconomic change that began to occur in Brazil in the mid-2000s, at the hand of the Workers Party's Luis Inácio Lula da Silva.

Inclusion has always lurked here, probably since even before the abolition of slavery in 1888. The question was only when Brazil's symbiotic relationships among rich, middle class and poor would allow (or need) social change to happen on a scale beyond trickle-down economics. The year 2004, 19 years after a military government (product of a 1964 coup) and a decade after an effective plan to end hyperinflation (following several failed attempts) seems to have been the right moment. On taking office in 2003, Lula's government expanded an existing income transfer program, raised pensions and the real minimum wage, increased credit access and instituted of other measures aimed at socioeconomic inclusion.

His popularity and federal spending led Rio's politicians, historically at odds with each other and with Brasília, to clamber onto the presidential bandwagon. Thus was born an unusual (and now-defunct) three-tier alliance among the federal government, Sérgio Cabral, elected governor in 2006 and again in 2010, and Eduardo Paes, elected mayor in 2008 and again in 2012. Both Rio politicians immediately cleaned up government finances.

As if this were not good enough for the city, in decadence since the capital moved to Brasília in 1960, Brazilian and foreign oil and gas industries, focused on pre-salt finds deep below the ocean off the state of Rio, began to boom, with new investment and oil royalties pouring into state and city coffers. 
This local boom, in a context of national economic growth, fueled by commodity exports, raised hopes (and expectations) for just about everyone in Rio. Before long, Cariocas would be euphorically changing their Facebook cover photos to pictures of the city's gorgeous landscape, famously cited by the American poet Elizabeth Bishop, who lived here in the fifties and sixties, when she wrote that visitors would likely think that "Rio is not a beautiful city, but a beautiful setting for a city".

The setting was certainly a useful selling point. In the same year that Rio hosted the Pan American Games, 2007, officials got news that the 2014 World Cup would be held in Brazil, sure to feature Rio's famous Maracanã stadium. And they submitted Rio's application to host the 2016 Olympics (in 2009, the UN would choose the city for its Rio + 20 environmental conference and in 2011, the Vatican would select Rio for a papal visit in 2013, during the World Youth Day conference). Security for these mega-events would have to be more than simply bringing in tanks and soldiers, as Rio did during the UN Environmental Conference here, in 1992.

There were so many reasons then, in 2007, to at last do something deep and lasting about Rio's homicide rate, about police killings -- about the general levels of violence that were encroaching on everyone's lives, particularly those of favela residents.

Ask around Rio today for the origins of pacification, and you'll hear about an official trip to learn about violence reduction in Medellín, Colombia; guidance from a discreet group of businessmen and economists; and the Brazilian Army's peacekeeping experience in Haiti, starting in 2004.

According to a former Beltrame colleague who ate a lot of lunches with him, however, the real roots of pacification are in the impossibility of having a delicious and healthy meal anywhere near the train station, halfway down the broad expanse of Presidente Vargas Avenue. As the Public Safety Secretary himself recounts in his 
memoir, a small group of top officials, taking stock of the situation on moving in, quickly addressed the deficit. Sharing the expense, they hired an in-house cook.

During meals, the group customarily hashed over work. They talked about the idea of occupying favelas. This had been done previously, but now the thought was to specially train recruits, move into a favela in one fell swoop, and slowly "contaminate" other areas.

One day in 2008, someone brought up a visit that the governor's wife was supposed to make to a day care center in the small South Zone Santa Marta favela. Local cops had nixed the visit, saying it would be unsafe, as drug traffickers had taken over the center. Someone suggested this be the first occupation. Dessert and coffee were served, and pacification - as the media came to call it -- was born.

The planning for additional occupations came later, says Beltrame's lunchtime companion. "Unidade de Polícia Pacificadora" (Pacifying Police Unit) was first uttered by a Military Police official; no one had time to think of anything better.

Working back then as foreign non-fiction editor at a publishing house, I didn't notice when the governor's wife made her visit and pacification began, with one outpost in December 2008. Like many Cariocas, I'd carved out a life within the limits of urban violence, and paid little attention to what went on in poorer areas.

The year 2009 saw four more pacification units installed, but with all the editing and reading I had to do at work, I was only vaguely aware of this. Also, I was devoting much of my free time to an apartment search. I wanted something with an ocean view. But ocean-view prices, even before a real estate boom began later that year (with news of the 2016 Olympic Games), were out of my reach.

In July 2009, I signed an agreement to buy a place in the rundown section of Ipanema contiguous both to Copacabana and the Cantagalo/Pavão-Pavãozinho favelas. 
In October, Rio made its final presentation to the International Olympic Committee, in Copenhagen. The city's delegation included Captain Priscila de Oliveira Azevedo, commander of that initial Santa Marta pacification unit (in 2007, herself a kidnapping and torture victim), part of a key promise to provide adequate security for the Games.

The Olympic Committee selected Rio - and two weeks later, drug traffickers in the Morro dos Macacos favela downed a police helicopter trying to quash a battle between rival drug gangs. Three cops died. All bets were off.

Ipanema friends thought the newly-opened subway station in General Osório Square would bring North Zone riffraff to the beach and hurt property values. But by December 2009, with the occupation of the hilltop Cantagalo and Pavão-Pavãozinho favelas, I thought perhaps I'd made a smart buy.

In April 2010, I wrote a final check and got the keys to my new apartment, already worth a good deal more than I'd signed for. Meanwhile, Rio inaugurated a pacification unit in its very first favela, Providência, which dates to 1897. At month's end, without firing a shot, the BOPE occupied seven tough favelas in Tijuca, not far from Maracanã Stadium. "We could have sent in a Boy Scout," the operation commander was quoted as saying in $O$ Globo. Pacification seemed to be picking up speed, with plans for a unit in the very same Macacos favela where the police helicopter had crashed.

Brazilians, who've lived through dozens of government plans, projects and promises, are born cynics, forcing people like me to keep my upbeat nature under wraps. But now, for the first time since I'd moved here from São Paulo, in 1995, idealism was not a totally laughable mental construct. In June 2010, I participated in a workshop with two Rio architects who asked us to imagine what the city would look like in 2050 and create a postcard from the future, to that effect. A French urban planner amongst us 
did the unthinkable, mapping Rio such that its center was in the decrepit North Zone and Copacabana was marked "Old Rio".

As I began to feel hopeful about Rio, I worried about continuity. Once the 2016 Olympics were over, would the royal coach turn back into a pumpkin and the coachmen back into mice? Would my new neighborhood fall back into deterioration? What would it take to keep on track?

With the idea of lending a hand in the arena of communication and debate, I left my job and started the bilingual RioRealblog, returning to journalism for the first time since the 1980s.

In those days, in São Paulo, I had visited favelas, always in the company of a priest. The Catholic Church, still in its Liberation Theology phase, helped favela residents to organize and make demands on government.

Now I began to visit favelas again - and could do so, in pacified favelas, on my own. One day in October 2010, I was invited to attend the first meeting of Borel favela residents with the Social UPP. It was held on a public school's top-floor terrace, overlooking the favela, sprawling down a hill.

The Social UPP was a new state agency, set up to coordinate social needs responses in pacified favelas; its initial work, said coordinator Ricardo Henriques, was to listen "strongly" to residents' demands, needs and wishes.

Having been brought up with Robert's Rules of Order, having attended too many Brazilian meetings, I was apprehensive about this one. How would Henriques manage Brazilians' penchant for affective connection - networking -- over simply getting things done?

Social UPP staffer Sílvia Ramos ably emceed the meeting from start to finish, allowing participants to express their individuality and make demands, too. Henriques and other city officials defused the situation, apologizing for decades of neglect. A 
community leader, speaking with a touch of rage, said Borel didn't want "top-down action", but "dialogue on a basis of equality". A three-page wish-list was read: internships, jobs, day care centers, entrepreneurship training, cultural and sports events, sewage systems, normal electric power service, trash collection, environmental education, vehicular traffic management, legal aid, women's health.

A priest who had worked in Borel since the seventies praised the police, noting he'd never done so in his life.

What a relief; the residents had spoken and it looked like real change was on the way. Even better, as I headed across the terrace toward the door, guided by the school principal, she claimed that real change had already occurred. Before pacification there was shooting every day, she said. Students could hardly concentrate, terrified of stray bullets and fearing for their families beyond school walls. Before pacification, when the police sporadically invaded the favela and asked to use the drinking fountains, the principal never let them in.

“The traffickers were always watching," she said. "I couldn't even point in the direction of the hill." I took a picture of her pointing in the direction of the hill, smiling.

The year 2010 was when we all woke up to the fact that something new was going on in our city. Eight more pacification units were created, for a total of 13, but more impressive than this, or the debutante balls and community soccer games the police had begun organizing, was the late November military/police invasion of the Vila Cruzeiro and Alemão Complex favelas.

The Rio police did have a plan: install forty pacification units before the start of the 2014 World Cup, mostly in areas attractive to tourists and where success would also bring support from the South Zone middle and upper classes. They hired fresh recruits and trained them (briefly), not to fight a war, but to prevent violence. This, not crushing drug traffic, was the goal, Beltrame said repeatedly. 
There were no surprise invasions or attacks; each UPP, as the units are denominated by their Portuguese acronym, was publicized and preceded by the BOPE. This Military Police elite squad would "retake" territory previously ruled by drug traffickers or paramilitary gangs, or both, making arrests and driving big criminals out. Once the area was deemed secure (which could take months), the UPP police would arrive, and begin working out of a donated shipping container. Usually, not a shot was fired. Residents were mostly pleased and Brazil's media empire, Globo, made no effort to hide its full support for pacification, avoiding criticism of it.

No one in the mainstream wondered about the use of the word pacification, nor the idea of "retaking" territories that had never been in full government purview. Little formal thought was given to the power vacuum left by departing narcos, who normally rule like feudal lords, settling disputes, meting out punishments, and taking up with any number of women. There was, however, talk of "integrating" the city, divided between formal and informal settlements, long dubbed "asphalt" and "hill" by locals. Not too many people had any idea of what integration meant, but the main thing, government officials said, was that citizens of the asphalt and citizens of the hills should have equal access to public services and share equal responsibilities.

Beltrame had consciously decided to install the early pacification units in smaller favelas, with the understanding that criminals would most likely leave them, and gather in Cruzeiro and Alemão. But in November 2010, car, truck, van and bus torchings started again - 96 incidents in just five days, across the city -- reportedly per the orders of imprisoned drug traffickers displeased with pacification. Police intelligence indicated that the Red Command, particularly in Vila Cruzeiro and Alemão, was ordering up the violence that was paralyzing the city. Governor Sérgio Cabral made a special request for Army and Navy help.

$3^{\text {RASILIANA- Journal for Brazilian Studies. Vol. 4, n.2 (2016). ISSN 2245-4373. }}$ 
No Carioca can forget the GloboCop footage of purported drug traffickers on a zigzagging dirt road running through a gravel quarry, fleeing Vila Cruzeiro to Alemão.

About a hundred armed men wearing backpacks were running, riding motorcycles, crammed into the back of a pickup truck, shooting and being shot at by a Civil Police helicopter - live. This was far more gripping than either of the Elite Squad movies (the second of which, portraying ties among cops, paramilitary gang members and corrupt politicians, was launched six weeks earlier, garnering wild applause in theaters, when the main cop character punches the main politician-paramilitary character).

The real-life drama sent South Zone residents scrambling to Google Maps. The North Zone had these "complexes", and to most of us they all seemed the same - poor and unsafe places to zip by on the way to the airport. In those days, only five years ago, maids and manicurists didn't say where they lived and to tell the truth, nobody asked them. Having no formal address, they couldn't even receive mail there.

We hadn't expected the "retaking" of these sprawling favelas to be so easy, but there went the bad guys on that zigzagging dirt road from Vila Cruzeiro to the Alemão Complex. Soon, many of them also fled Alemão, crawling through water runoff pipes, masquerading as priests or appropriating workers' uniforms). The cops, according to TV Globo, had ultimately expected to face off with about six hundred men, a bloodbath ensuing.

But a city long assailed by a network of mafias, with little help from hamstrung journalists, tends to develop myths. At the time of the Cruzeiro/Alemão invasion, domestic workers living in the sprawling South Zone favela, Rocinha, still held by

"Nem", one of Rio's most sophisticated drug traffickers, gossiped with their South Zone ladies of the house. Nem was said to have a weapon capable of bringing down a helicopter. He was installing land mines in the brush around Rocinha. He'd 
built a bomb out of a stove, filled with nails and metal bits, meant to be set up on a curve near the local health clinic.

A year later, the indomitable Nem was arrested trying to smuggle himself out of town in a car trunk.

Back in 2010, the easy success was much celebrated. "Rio's Soul Washed Clean" read the $O$ Globo headline. Disque Denúncia's phones rang wildly with tips on the whereabouts traffickers, their weapons and drugs, with a record 1,136 calls on the actual day of the 2010 Alemão invasion. It was said that in early 2008 construction contractors had had to make a deal with traffickers to start work on the federally-funded cable car system stretching over Alemão (inspired by the Medellín recipe of grand public works in concert with improved policing). How ludicrous this now seemed, as we crowed over footage of their desperate flight!

Herewith South Zone residents began to revel in the luck they had to live in Rio de Janeiro, now truly living up to its "Marvelous City" nickname. You couldn't scroll through Facebook without seeing dozens of cover photos of the Sugar Loaf, Corcovado, and the Two Brothers peaks. We weren't such awful people after all! Rio's long brain drain turned into brain gain, with young Cariocas coming home from abroad, and southern Brazilians moving here to work in tech, design, startups.

The euphoria wasn't ubiquitous. Residents in the occupied favelas complained that police and soldiers were kicking in doors, invading their homes and stealing money and belongings. Soldiers were then prohibited from carrying backpacks and mobile offices were set up to take complaints. Still, police often stopped and frisked young men and boys, in favela streets and alleys (and still do).

Much later, Alemão (and Rocinha, too) would become one of the most problematic examples of pacification. But the 2010 invasion garnered wide support for 
the new public safety policy, and marked a shift in the direction of that perplexing goal: urban integration.

I did my part. O Globo newspaper ran a profile of 17-year-old who'd been publishing a community newspaper in Alemão since the age of twelve. He and other youngsters covered the invasion with real-time tweets. I was one of the people who took his Twitter following from 180 to more than 20,000, in one day. Soon, René Silva was on Facebook, too. The cool thing? You could ask him stuff. Rio's favelas, which didn't even get onto city maps until the 1980s and are home to 1.2 million, almost one out of five city residents, were at last starting become visible to the rest of the city.

Police uniforms (with pink furry handcuffs, for lady cops) sold like hotcakes for Carnival costumes, in 2011, 2012 and 2013.

The occupation of Complexo do Alemão and Vila Cruzeiro expanded support for the new pacification policy, but old-fashioned politics were still alive and well. Less than a month after the invasion, just before Christmas, Rio Governor Sérgio Cabral quietly passed the Social UPP over to the municipal government. In order to maintain his state and federal alliance with the Workers' Party, he needed Ricardo Henriques' position for one of its members, who would go on to become mayor of neighboring Niterói.

This was just the tip of the iceberg that would slowly be revealed to us, despite Secretary Beltrame's mantra that the police couldn't be held responsible for all of Rio's favelas' needs. Clientelist politics permeate city and state agencies, many of which are run like fiefdoms meant above all to promote politicians' ambitions. And so they are unwilling or unable to work together to effectively meet citizens' needs. Thus, seven years into pacification, in 2015 -- despite some advances -- sewage continues to course down favela alleys, trash piles up, youth programs don't develop. Trust between residents and government is constantly undermined. 
Meanwhile, pacification began to show results, with homicides as reported by the official Instituto de Segurança Pública dropping from a rate of 40 per 100,000 in 2007 to 30 per 100,000 in 2010. Police killings also dropped, particularly in areas with UPPs, from almost 20 per 100,000 inhabitants in 2009 to only about seven, in 2010.

In 2011, the year that took the number of UPPs to 18, I wrote a blog post about an innovative youth program, a sort of incubator for favela startups, called Agência Redes para Juventude (Agency for Youth Networks). Its creator, Marcus Faustini, liked what I wrote and offered me a short-term reporting job that turned out to be a valuable chance to observe the social change that pacification was making possible.

One night, after walking down the alleys of the Pavão-Pavãozinho favela after a stirring jazz music school inauguration, skirting dog poop, peering into lit-up windows, I suddenly found myself on a Copacabana street, three minutes from my apartment. Those dreams where you're in a place you know, slightly modified, came to mind. How could I have thought I knew my neighborhood?

Himself a product of a housing project in the city's isolated West Zone, Faustini designed a program bringing in mentors, specialists and celebrities to help low-income youth with their startups, an artificial re-creation of the networks that middle-and upper-income youth count on, naturally. The favela kids also helped each other, crisscrossing the city, visiting formerly off-limits neighborhoods and creating their own lasting network. I'm still in contact with many of these young people. Through Facebook and sometimes by way of personal contact I have watched them gain confidence, go to college, take initiative and show the way for those coming up behind them. Some of them, growing out their hair natural (as rarely seen before here), bring new energy to Afro-Brazilian movements.

Midway through 2012, the Rio police received the results of the first serious impact study of pacification. Funded by the Development Bank of Latin America by 
way of the Brazilian Forum on Public Safety, the study found that pacification saved lives: about sixty a year per 100,000 inhabitants at that time, or 177, when UPPs served a total population of close to 300,000 .

The study also found that inside and near UPP favelas, fewer police killings were the single most significant factor in reduced lethal violence. UPPs were pacifying the police.

But the study (not accompanied by a parallel evaluation of the Social UPP) pointed to serious failings. These included a lack of systematized police work criteria and procedures, poor labor conditions and inadequate training.

Improvisation has brought Brazilians well-deserved fame for their flexibility and creativity. Unfortunately, it works against planning, accountability and transparency and favors clientelism. Clientelism is all that many favela residents know, accustomed as they are to bringing problems to the local drug boss. Without systematized protocols, UPP officers deal unevenly with the post-pacification power vacuum, with residents left longing for the clear rules of the narcos. Often, locals complain that UPP commanders unjustly ban community and family parties, as well as the funk dances that (usually held by traffickers) have long spiced up favela life.

The above description is in the present tense because the UPPs didn't adopt most of the 2012 study's essential recommendations, focused on police professionalization and improved community relations.

Though a favela youth vanguard is still breaking new ground and encouraging urban dialogue, Rio's 2010-2012 euphoria is but a dim memory. By now, in mid-2015, just about everyone agrees that the lurching pacification train, if not off the track, has all too slowly chugged forwards and backwards and made too many unscheduled stops despite the fact that we're now up to 41 UPPs.

RRASILIANA- Journal for Brazilian Studies. Vol. 4, n.2 (2016). ISSN 2245-4373. 
Of course, the good times are over for everyone. Oil prices have nose-dived, commodity exports dried up and Brazil is in the midst of a recession and the worst corruption scandal ever, all but paralyzing Rio's prime sources of investment and jobs: the Petrobras state-run oil giant and its suppliers, and top construction companies. The 2014 elections broke apart the governmental alliance that had stoked Rio's turnaround starting in 2006. I haven't checked, but I'm sure my apartment has lost value.

What happened to our pioneering new public safety policy, guided by that serious, honest blue-eyed visionary from the South? Most serious observers still believe the train is heading in the right direction. But, they say, part of the problem is who's been conducting it.

The year 2012 saw the biggest expansion of pacification, with an additional ten units, bringing the total to 26 UPPs. With so many mega-events in the offing, there was pressure on Beltrame. This was the year that internal police issues - power struggles, competition, lack of coordination and collaboration -- began to eat away at the policy. Given the impossibility of a complete reorganization of Brazil's police forces (a constitutional amendment is what this would take, deemed impossible in the face of strong entrenched interests) Beltrame had, in late 2009, instituted Integrated Public Safety Regions, setting Military and Civil Police units to work together, to meet goals for pay bonuses, and bring down crime by region.

Experts say that this, though a key factor in crime reduction, isn't enough to overcome the organizational shortcomings of the Rio police -- divided, authoritarian, adrenaline- and opportunity-for-gain-seekers that they are. And so, when UPP management was turned over to the everyday management of the Military Police in 2012, the expanded train crew brought these characteristics along with them.

"I support the demilitarization of the Military Police," says sociologist Ignacio Cano, whose Laboratório de Análise de Violência did the 2012 study and is still 
consulting with the police to reduce lethal cop violence. "But I tell them, jokingly, that if they are going to demilitarize, they must first re-militarize. It's a chaotic institution, of fiefdoms, resistance, inertia."

If 2012 was the year of internal police problems, 2013 was the year of trouble on the outside.

The first signs appeared in January of that year, which put eight more UPPs on the map, bringing the year-end total to 36. A resident of Chapéu Mangueira, a pacified favela behind the asphalt neighborhood of Leme, just next to Copacabana, told me that a Friends of Friends gang drug trafficker and his men had arrived one night carrying weapons and wearing black hoods, interrupting an outdoor party. Ever since then, there had been nightly shooting, frightening residents now used to relative peace. Although they knew the narcos were still in business, their weaponry, from the June 2009 UPP arrival until January 2013, was hardly in evidence.

The favela in question, together with its neighbor, Babilônia, had been considered a model of pacification. VIPs such as former New York mayor Michael Bloomberg and Harrison Ford, along with his family had visited, stopping at the Bar do David, famed for its seafood feijoada (stew). This was a favela that had gotten the attention of municipal and private sector agents, with improvements in drainage, sewage collection, water supply, reforestation, public lighting, mudslide prevention, the creation of leisure areas, and small-business training. Pacification had stemmed an exodus from nearby apartment buildings on the asphalt, raising real estate values.

The question of the hour, now, was where were the pacification police? Had they been paid off to look the other way, or were they simply incompetent? The answer was never made public, but Beltrame did change the UPP commander, in February.

The backstory was that a drug gang leader had gotten out of jail and returned to retake his territory. This was starting to plague other favelas as well, pointing up yet 
another weakness of Rio's new public safety policy: inadequate coordination with the justice system, plagued by loopholes that allow too many criminals to get out of jail too soon.

Beltrame told Veja newsmagazine that such reversals were to be expected. What neither he -- nor anyone -- expected were the massive mid-2013 demonstrations in the streets of Rio and many other Brazilian cities, just as the Confederations Cup kicked off.

I marched, along with my 23-year-old son and a Portuguese journalist, and thousands more. Carrying banners, chanting "The giant has awoken" and "Come down to the street", we filled up all eight lanes of Presidente Vargas Avenue. To our right, over the heads of the thick crowd, I spied the Eastern Military Command headquarters (formerly the War Ministry), and then, of course, the train station, with DisqueDenúncia and the state public safety secretariat atop it, crowned by its art déco clock.

Every so often, the crowd peacefully performed a sort of wave, quickly sitting, then standing. This, plus the blinking apartment lights, in solidarity, of the avenue's one residential building, and then the crowd of photographers above us on an overpass by the Sambadrome, made us feel united and powerful.

Bus fare hikes had brought us to the march (I'd started riding them once the city set up dedicated lanes and demarcated stops, in 2011). But these were merely emblematic of the real (and lasting, in my opinion) draw: the persistence, despite the changing shape of Brazil's socioeconomic pyramid, of a two-tiered system, one for the rich and one for the poor, providing transportation, health care, education and so much else.

Another wave. My son helped me to my feet and we moved ahead with the crowd.

On the left, we passed the spanking new headquarters of the state sewage and water company, Cedae, to this day still blind to the water shortages and open-air 
sewage channels that plague many favela residents. Even my neighborhood in Ipanema is poorly served, with chronic sewage leakage and zero treatment. All effluent goes out to sea.

As we approached City Hall, set back from the avenue just as it comes to an end, the marchers slowed. Feeling a little claustrophobic, I looked at my companions. Just then, the first in a single-file line of shirtless muscled young men shoved me aside, headed in the direction of the mayor's office. Tied around their faces, $t$-shirts covered nose and mouth.

“Let's go," I urged. These, we later learned, were the "black bloc" members who vandalized public and private property during the marches and rallies of 2013 and 2014. That night, as we hunted down a bus to carry us away from the crowds, they set to work - and so did the police.

From news and Facebook reports of those who were there, the lack of preparation was quickly evident. Cops would not or could not distinguish the vandals from peaceful students taking cover in the Bohemian haunts of Lapa. Tear gas, flash bombs and rubber bullets were liberally used - and this happened again and again that winter, with neighbors of the Governor's Palace in Laranjeiras, a prime protest location over several months, complaining about clouds of tear gas invading their apartments. It happened so much that the Porta dos Fundos online comedy troupe created a skit of a Military Police classroom training session. A uniformed student, in answer to the instructor's every question, can only babble, "rubber bullets".

This was a far cry from the applause for the cop in Elite Squad 2, from the testimony of the priest in the Borel favela, or Rio's soul being washed clean as Alemão was retaken. In 2014, some other Carnival costume would be the dernier cri.

In January 2015, Veja newsmagazine broke a story revealing the depth of police brutality back in 2013. Evidence from an internal police investigation included a 
whatsapp group conversation among a military police soldiers and their commander, inciting each other to murder and referring to Nazi behavior as a positive example.

One could hope that the brutality was limited to regular military police who hadn't undergone pacification training, but this was not so. A month after the street protests began, Amarildo, a poor resident of the Rocinha favela, father of six, went missing. Demonstrators quickly took up his cause, asking, via social media and on banners carried in the streets, "Where is Amarildo?"

His body was never found, but investigations so far (still ongoing) indicate that UPP cops tortured Amarildo to his death, then called in the BOPE elite squad to make off with his remains. A Military Police inquest revealed that the then-commander of the Rocinha UPP bribed a resident to incriminate a drug trafficker in his death.

As 2013 progressed, and we rounded the corner into the year of the devastating Brazilian World Cup plus the destabilizing gubernatorial and presidential elections, $O$ Globo newspaper persisted with titling its UPP coverage under the rubric "advance of pacification". It sounded so hollow.

Yes, we got two more units in 2014 , for a total of 38 , missing the goal by two. But crime was on the rise again, as were police deaths, killings, stray bullets and corruption investigations. Last September, the Military Police's Special Operations Commander was arrested, along with more than twenty other cops, for taking bribes from drug traffickers.

Still, Luiz Fernando "Pezão" (Bigfoot) de Souza, the previous governor's VP, was elected, signaling voter support for some degree of continuity of Rio's public safety policy. Beltrame stayed on in his job, and brought back three top officials, reformers.

And the Social UPP (renamed Rio + Social, or More Social Rio), late last year, launched a pact, calling on public agencies, the private sector, academia and NGOs to work together to meet social needs. 
In April of this year, I had coffee in Ipanema with a talented musician from Alemão Complex, whom I'd met through the Agência.

We shared the sense of doom assailing everyone in Rio (although this was a month before the fatal knifing of a cyclist on Rio's Rodrigo de Freitas Lagoon -- which brought on enormous debate over proposals to prosecute some juveniles as adults). Fighting in Alemão between traffickers and cops had escalated since January, to the early April shooting death of a ten-year-old boy as he sat just outside his house, playing with a cell phone.

The musician had described for me the hardships of Alemão, where he creates cultural projects. In recent months, police had taken to sitting on the steps to his house. He was afraid to tell them to move, yet knew the narcos would dislike what they would certainly perceive as hospitality.

I tried to cheer up my friend by telling him about a newly-launched campaign for drug decriminalization, featuring cartoons on the backs of Rio buses. "Repressing drugs kills more than using them," says one, featuring a smoking gun head to head with a lit joint. "We need to bring this debate to Alemão," he said. "People there still think the drug war should continue".

Neither of us knew then that the Rio crime statistics were starting to improve once more, that Beltrame has set up a broad-based "pacified territories" council or that his new team is carrying out a non-favela community policing experiment that's met with initial success. Even if we'd known, we wouldn't have given such news much time in our conversation. I'd heard that the new team was also evaluating the UPPs and working to reduce violence in the questionable ones. But now, with shrinking state revenue, it all seemed so complicated.

Maybe, back in 2008, someone should have questioned the media's term, "pacification", which sounds as simple as putting a cloth over a canary's cage. But 
another name (community policing?) might have promised too much or (violence reduction/urban integration units) sounded too challenging.

Cariocas are said to be bipolar, gleeful one moment, horribly depressed the next. I don't agree. But they are, often, so self-involved that they can't perceive just how much they are akin to other, non-Carioca human beings. Any new policy or technology has its ups and downs; instead of appreciating nuance and finding the patience for big-picture analysis, humans tend to readily identify these as success or failure. Embrace or rejection are our go-to options.

And so I should say that the story of public safety in Rio de Janeiro, from 2007 until today, in the context I've tried to describe here (and I didn't mention the huge amount of Facebook networking, videoing, discussion and communication taking place) is one that has challenged assumptions and roles. We've all had new experiences and we've all engaged in debate. And I see a few basic certainties emerging.

No longer will the traditional middle and upper classes be able to blithely send in the (Military Police) troops to shoot a few drug traffickers and uninvolved favela residents and get the situation under control. No longer can the Rio police blithely shoot people and then get on with their political and business partnerships. A shift has begun, away from authoritarianism, towards democracy. If this sounds too optimistic, in view of current job and income losses, plus lasting cronyism, then let's just say that the fundamental change is that people now believe that Rio doesn't have to be the way it's always been. Which is huge, for a society so marked by slavery and Portuguese court politics.

I do feel more like a real carioca now, a cynic burnt by unkept promises and lazy thinking. Still, I see reason for hope: Rio's young people, whose formative years matched those of Brazil's recent boom. "I don't care about the change that already happened," Alessandra Orofino, a twenty-something co-founder of Meu Rio, a 
watchdog and activist group told me, one day in 2013 when I was trying to provide some historical perspective. "I want change now!"

My musician friend and I were sipping our coffee on the terrace of my local haunt, at the end of a sunny day. I wondered how at home he felt, in Ipanema. "It's a completely different world here, so removed from mine," he said. Hordes of young beachgoers walked past us, on their way not to the subway (comparatively expensive), but the nearby stop for North Zone buses, including the one that goes to Alemão Complex.

Trying to build some sort of bridge between our worlds, I told him a story of my own. In 1998, when I lived in a big house near Rocinha, I heard that the Civil Police had kidnapped the favela's druglord, releasing him after his men paid a forty thousand real ransom. In the celebratory shooting after his return, a young girl bled to death of a bullet wound, in the street. Outraged, I called a local newspaper, and then bragged to my husband and some Brazilian friends.

I got so much flak from all of them - they said I'd put my family's lives in danger - that I fell ill and took to my bed with a fever. "I was so scared! I felt like such a dumb gringa!" I told the musician. "My husband said the paper might have caller ID, that the police might force them to identify me."

“You remember how afraid you were in 1998?" he asked me, leaning forward over his little coffee cup. "I'm that afraid every day in Alemão. Afraid of the traffickers and afraid of the police." 